\title{
Fulfillment of the expected roles of a medical teacher: Role of the Medical Education Department
}

\begin{abstract}
Shrivastava, S. R. ${ }^{1}$ \& Shrivastava, P. S. ${ }^{2}$
Abstract

The effective delivery of medical education to the aspiring students is a tough ask and it extends way beyond the delivery of knowledge. This is primarily because of the expectations of the community in terms of accountability, advances in the field of medicine, and the wide range of challenges which a student has to go through in the training period or the system has to face in terms of training number of students with the existing resources. In order to respond to these challenges, it is a must that the teachers keep improving their skills in all the roles expected of them and there arises the need to have a dedicated Medical Education Department (MED) within the institute. In conclusion, the constitution of a medical education department is a must in each and every medical institution. The department can play an important role in strengthening the teaching-learning, research activities, and improving the services profile of all the departments.
\end{abstract}

Keywords: Teaching, Educational research, Medical education

\section{Introduction}

The effective delivery of medical education to the aspiring students is a tough ask and it extends way beyond the delivery of knowledge (Castillo, et al., 2014). This is primarily because of the expectations of the community in terms of accountability, advances in the field of medicine, and the wide range of challenges which a student has to go through in the training period or the system has to face in terms of training number of students with the existing resources (Castillo, et al., 2014, Batool, et al., 2018). In order to respond to these challenges, ${ }^{1}$ Medical Education Unit Coordinator and Member of the
Institute Research Council, Department of Community Medicine, Shri Sathya Sai Medical College \& Research Institute, Sri Balaji Vidyapeeth - Deemed to be University, Ammapettai, Nellikuppam, Chengalpet District, Tamil Nadu, India ${ }^{2}$ Department of Community Medicine, Shri Sathya Sai
Medical College \& Research Institute, Sri Balaji Vidyapeeth - Deemed to be University, Ammapettai, Nellikuppam, Chengalpet District, Tamil Nadu, India

Corresponding Author:

Dr. Saurabh RamBihariLal Shrivastava MD, FAIMER, PGDHHM, DHRM, FCS, ACME.

Professor, Department of Community Medicine, Shri Sathya Sai Medical College and Research Institute, Sri Balaji Vidyapeeth (SBV) - Deemed to be University, Thiruporur - Guduvancherry Main Road, Ammapettai, Nellikuppam, Chengalpet District, Tamil Nadu - 603108, India

Email:drshrishri2008@gmail.com it is a must that the teachers keep improving their skills in all the roles expected of them and there arises the need to have a dedicated Medical Education Department (MED) within the institute (Batool, et al., 2018, Davis, et al., 2005).

\section{Role of Medical Education Department}

It is expected that the MED has to fulfil multiple roles, with regard to research, teachinglearning, conduction of faculty development programs, planning \& implementation of curricular reforms, evaluation of newer initiatives, etc. (Davis, et al., 2005, Ali \& Shamim, 2014). Establishing a culture of performing educational research could be one of the most important contributions as almost all the faculty members are carrying out research in their own specialty and research in education has been ignored (Batool, et al., 2018, Ali \& Shamim, 2014). The department can help in guiding researchers about the methodology to be adopted and publishing the findings of the study to ensure its wide distribution. The department can help the teachers to improve their teaching skills and students' engagement in both large \& small-group teaching session (Davis, et al., 2005, Ali \& Shamim, 2014, Varpio, et al., 2014).

DOI: http://doi.org/10.4038/seajme.v14i2.282

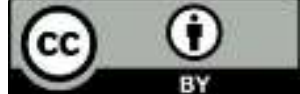

156

(C) SEAJME. This is an Open Access article distributed under the terms of the Creative Commons Attribution License (http://creativecommons.org/licenses/by/4.0/), which permits unrestricted use, distribution, and reproduction in any medium, provided the original author and source are credited 
In addition, it can aid in the designing of educational materials (like modules in elearning, course materials of new courses, etc.), planning and implementation of new innovations (such as simulation or standardized patients, use of online tools, etc.), and strengthening of the assessment framework (Castillo, et al., 2014, Batool, et al., 2018). Further, the process of curriculum development (such as fellowship course or certificate course, etc.) and evaluation of the same can also be streamlined by the active inputs of the medical education department. In the long run, the MED can empower the faculty members to effectively discharge all the roles expected of them by means of the conduction of workshops or sensitization programs (Ali \& Shamim, 2014, Varpio, et al., 2014). Moreover, the department of Medical Education can help the faculty members from other departments on various issues of teaching-learning, promotion of evidence-based learning and for nurturing their academic careers to become medical educationists in the future (Davis, et al., 2005, Varpio, et al., 2014).

\section{Setting up a Medical Education Department}

The process to set-up a MED in an institute might vary between different institutions, nevertheless it generally includes support from the dean \& other administrators, appointing a coordinator who is qualified to perform the job, formulate the vision-mission and the profile of activities which will be strengthened by the department (Varpio, et al., 2014, Al Shawwa, 2012).

\section{Administrative structure of a Medical Education Department}

The organization of a Medical Education Department depends on whether it is within the medical school or within the university. It is generally headed by the Dean of the institute and is manned by a team of qualified personnel with varied professional backgrounds (educationists or medical teachers). These personnel should be a combination of junior and senior staff, and should also be assisted by technical and supporting staff (Davis, et al., 2005, Al Shawwa, 2012). The department will have a Coordinator, who will be the functional in-charge of all the medical education related activities. The size of the team is variable and it is preferable to have those people who possess some qualification in medical education (viz.
$\mathrm{PhD}$ in Education and/or Medical Education, MD with master and/or PhD in Medical Education).

\section{Medical Education Unit}

The Medical Education Unit of Shri Sathya Sai Medical College and Research Institute, a constituent college of the Sri Balaji Vidyapeeth, Puducherry, has been functioning for more than 10 years. The Unit is actively involved in carrying out different faculty development programs, conduction of revised basic course workshops, curriculum implementation support programs, sensitization programs on different teaching-learning methods, etc. Moreover, the Unit has always taken the lead in planning and successful implementation of the competencybased medical education for undergraduates and the foundation course, and is thus helping the faculty members to be more equipped to discharge their roles and responsibilities effectively.

\section{Conclusion}

In conclusion, the constitution of a medical education department is a must in each and every medical institution. The department can play an important role in strengthening the teaching-learning, research activities, and improving the services profile of all the departments.

\section{References}

Ali, S.M. \& Shamim, M.S. (2014) Way forward for departments of medical education in Pakistan. J Pak Med Assoc 64, 7, pp. 7323.

Al Shawwa, L.A. (2012) The establishment and roles of the medical education department in the faculty of Medicine, King Abdul Aziz University, Jeddah Saudi Arabia. Oman Med J 27, 1, pp.4-9.

Batool, S., Raza, M.A. \& Khan, R.A. (2018) Roles of medical education department: What are expectations of the faculty? Pak J Med Sci 34, 4, pp. 864-8.

Castillo, M., Hawes, G., Castillo, S., Romero, L., Rojas, A.M., Espinoza, M. \& Oyarzo, S. (2014) The educational change in medical schools. Revista Medica de Chile 142, 8, pp. 1056-60. 
Davis, M.H., Karunathilake, I. \& Harden, R.M. (2005) AMEE Education Guide no. 28: the development and role of departments of medical education. Med Teach 27, 8, pp. 665-75.
Varpio, L., Bidlake, E., Humphrey-Murto, S., Sutherland, S. \& Hamstra, S.J. (2014) Key considerations for the success of Medical Education Research and Innovation units in Canada: unit director perceptions. Adv Health Sci Educ Theory Pract 19, 3, pp. 36177. 